\title{
Environmental Kuznets Curve in D8 Countries: Evidence from Panel Cointegration
}

\author{
Hüseyin İçen ${ }^{1}$ (C)
}

\begin{abstract}
The environmental Kuznets curve (EKC) hypothesis has become an important factor in environmental studies in recent years. D8 members have viable economic positions in their respective regions due to their natural resources, crowded populations and potential markets sizes. This study deals with the validity of the EKC hypothesis for D8 countries between the years 1972 and 2014. The main contribution of this study to the literature is to identify the relationship between carbon emissions, GDP and energy use variables in D8 countries. Thanks to the model used, the relationship in the inverse $\mathrm{N}$ and $\mathrm{N}$ form was estimated and turning points were calculated. Furthermore, this relationship supports the $\mathrm{N}$-shape environmental Kuznets curve hypothesis. In the light of these results, policymakers should immediately put policies in place that aim at reducing carbon emissions. The panel results of our study show that there is an inverse $\mathrm{N}$-shaped relationship. The country with the highest per capita energy use and the highest carbon emission is Turkey, followed by Indonesia. In Malaysia, however, increase in per capita GDP causes a decrease in the carbon emission of per capita energy use. Therefore, Turkey and Indonesia's clean energy use needs to take steps towards encouraging production which implements the policy.
\end{abstract}

\section{Keywords}

Environmental kuznetscurve, Panel cointegration, D8 countries

\section{JEL Classifications}

C33, K32, Q53, R11

1 Corresponding author: Hüseyin İçen (Ress. Asst.), Istanbul University, Faculty of Economics, Department of Operations Research, Istanbul, Turkey. E-mail: huseyin.icen@istanbul.edu.tr ORCID: 0000-0002-3368-3878

To cite this article: Icen, H. (2020). Environmental kuznets curve in D8 Countries: Evidence from panel cointegration. EKOIST Journal of Econometrics and Statistics, 32, 85-96. https://doi.org/10.26650/ekoist.2020.32.0011 


\section{Introduction}

Simon Kuznets's (1955) study revealed a relationship between income distribution and economic growth. According to Kuznets, income distribution would deteriorate with economic growth first, but then improve later as economic growth continued. In a study analogious to Kuznets's, Grossman and Krueger (1991) concluded that environmental pollution increases as income increases, but pollution decreases after a certain level of income. Because of the likeness of this curve to the Kuznets curve, illustrating the relationship between income and environmental quality, it is known as Environmental Kuznets Curve (EKC). The EKC hypothesis is illustrated in Figure 1 below.

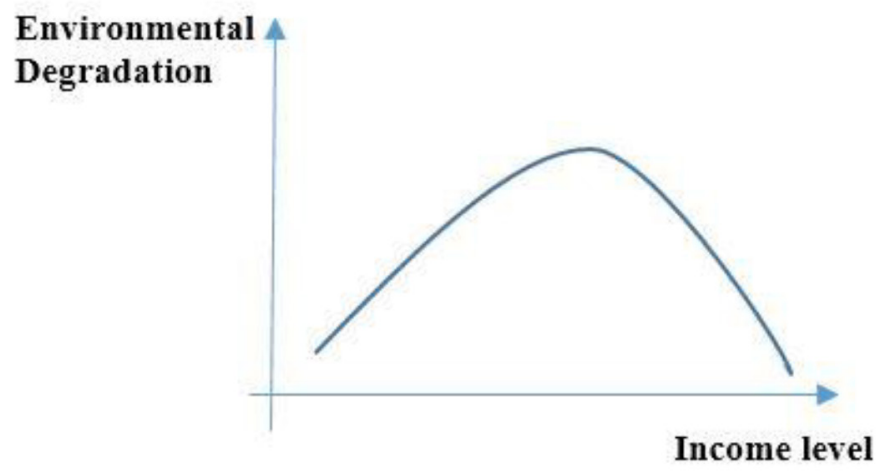

Figure 1. EKC Curve

Source: Dinda, 2004: 434

Initially, environmental deterioration increases with increase in income. When the income level exceeds a threshold level, pollution reaches the highest level. After this point, deterioration gradually decreases. There are several reasons for the eventual decrease in environmental pollution. First, as income levels increase, interest in a clean environment increases. Some economists think that the personal preferences of high-income people eventually lead to a virtuous environmental relationship between increased income and environmental degradation (Roca, 2003, p.9). Poor people need little environmental quality, but as a society prospers, its members can intensify their demands for a healthier and cleaner environment. Besides, more production means more waste and emissions that make up the environmental pollution. On the other hand, thanks to technological advances, more environmentally friendly production is possible. This is the technique effect of economic growth (Borghesi, 1999, p.7; Dinda, 2004, p.435). Another reason for the shape of EKC is the race to bottom scenario. Under this scenario, relatively high environmental standards in developed countries impose high costs on polluters (Dasgupta, et al. 2002, p.159). 
In the literature, the relationship between environmental pollution and economic growth is modelled in different forms. Pezzey (1989) and Opschoor (1990) argued that such reverse U-relationships may not be realized in the long run. They suggest an N-shaped curve that exhibits the same pattern as the inverted U curve (De Bruyn, et al. 1998).

Several econometric models empirically testing EKC have been established in the literature. The basic model explaining the EKC hypothesis can be explained as follows (Grossman and Krueger, 1991; Stern, 2004):

$$
C O_{2_{i t}}=\beta_{0}+\beta_{1} G D P_{i t}+\beta_{2} G D P_{i t}^{2}+\beta_{3} G D P_{i t}^{3}+\beta_{4} Z_{i t}+\varepsilon_{i t}
$$

where, $\mathrm{CO} 2$ refers to the carbondioxide gas emissions, GDP refers to the real per capita gross domestic product, $\mathrm{GDP}^{2}, \mathrm{GDP}^{3}$ the square and cube of GDP respectively, $\mathrm{Z}$ contains all other variables that might affect enviromental pollution and $\varepsilon$ is the error term. Energy consumption (as an exogenous variable) is an indisputable factor affecting environmental degradation. The model used in this study is given by Equation 1.2.

$$
C O_{2_{i t}}=\beta_{0}+\beta_{1} G D P_{i t}+\beta_{2} G D P_{i t}^{2}+\beta_{3} G D P_{i t}^{3}+\beta_{4} \text { Energy }_{i t}+\varepsilon_{i t}
$$

The variables included in the model are annual $\mathrm{CO} 2$ emissions per capita measured by metric ton, GDP per capita US\$, Energy refers to energy consumption $\mathrm{kg}$ of oil equivalent per capita. Where the square of income is taken to capture the inverted U-shape relationship and the cubes of income is taken to capture the $\mathrm{N}$-shape relationship. The signs of the parameters $\left(\beta_{1}, \beta_{2}, \beta_{3}\right)$ determine the shape of the Kuznets curve. Therefore, the existence of the EKC hypothesis can be verified or refuted (Dinda, 2004, p.441). That is;

If $\beta_{1}>0, \beta_{2}=\beta_{3}=0$, a monotonic increasing relationship between GDP and $\mathrm{CO} 2$.

If $\beta_{1}<0, \beta_{2}=\beta_{3}=0$, a monotonic decreasing relationship between GDP and CO2.

If $\beta_{1}>0, \beta_{2}<0, \beta_{3}=0$, an inverted U-shaped relationship.

If $\beta_{1}<0, \beta_{2}>0, \beta_{3}=0$, an U-shaped relationship.

If $\beta_{1}>0, \beta_{2}<0, \beta_{3}>0$, a N-shaped form.

If $\beta_{1}<0, \beta_{2}>0, \beta_{3}<0$, an inverted N-shaped form.

An Istanbul summit was held on June 15th 1997 and was represented by heads of States or Governments from the group of D8 established by Bangladesh, Indonesia, Iran, Malaysia, Egypt, Nigeria, Pakistan and Turkey. According to the Istanbul 
declaration, the purpose of D8 is to improve economic cooperation and increase trade among its member states. D8 members have viable economic positions in their respective regions due to their natural resources, crowded populations and potential markets sizes. Therefore, it is important to analyze the relationship between environmental degradation and income of the D8 countries who share similar characteristics. Indeed, examining the mentioned relationship will help in developing similar policies in these countries. In this study, the validity of EKC in D8 countries is analyzed by the method of panel cointegration .

\section{Literature Review}

Studies on the environmental Kuznets curve started in 1990s and have gained momentum in recent decades. The initial work was done by Grossman and Krueger (1991) to study the effect on NAFTA, but EKC claimed more attention and gained importance after Shafik and Bandyopadhyay's (1992) background study for the 1992 World Development Report, which stated that improvement in environmental quality is imperative for sustainable development'(Ahmed and Long, 2012, p.6).

A consideration of the empirical studies on the validity of the EKC hypothesis shows that different analytical techniques were used in various studies. The results are generally supportive of the EKC, though studies exist which indicate otherwise. When the studies with panel data are considered, the evidence tends to support a long-term relationship between income and enviromental pollution. Kasman \& Duman (2015), Gündüz (2014), Cho et al. (2014), Farhani et al. (2014), Osabuohien et al. (2014), and Lee \& Lee (2009) applied the panel approach of cointegration in order to test the validity of the EKC hypothesis. These studies also support the EKC hypothesis. Yerdelen Tatoğlu \& İçen (2019) found the EKC hypothesis valid in their study using the multi-dimensional panel data method for 66 countries between the years 1971 and 2014. Allard et al. (2018) investigated the relationship between carbon emissions and GDP for 74 countries between the years 1994- and 012. They observed the N-shaped EKC. Dong et al. (2018) obtained EKC-supported findings for 14 Asia Pacific countries covering the period between 1970 and 2016 using the panel cointegration methods. Shuai et al. (2017) used the panel cointegration method on their study of the data of 164 countries for the period between 1960 and 2011. They found that the $\mathrm{CKC}^{1}$ hypothesis was valid. On the other hand, the study by Zoundi (2017) conducted on 25 African countries provided opposite findings. Jebli et al.(2016) investigated the existence of an EKC in 25 OECD countries. Their results provided evidence to support the EKC hypothesis for the period between 1980 and 2010. Furthermore, Perman and Stern (2003), in the study covering 74 countries for the period between 1850 and 1990, concluded that the EKC hypothesis was invalid. There are studies modeling the $\mathrm{N}$ form of $\mathrm{EKC}$ for various countries (Brajer

1 EKC hypothesis is referred to as carbon Kuznets curve (CKC) hypothesis in this study. 
et all, 2008; Balın \& Akan, 2015; Baek, 2015). As can be seen, there is a very large literature dealing with the EKC on many countries. However, the results are far from being unanimous.

\section{Econometric Methodology}

\section{Panel Unit Root}

Whether one works with pure time series or panel data models it is necessary to examine stationarity of variables. When the panel data is generated with non-stationary variables, it is possible that spurious regressions occur using panel models, as in the time series analysis. Investigation of stationary in panel data models is possible with panel unit root tests. In the panel unit root tests, the cross-sectional dependence of panels should be taken into account. When the panel unit root tests first developed, the focus was on micro panels, and hence the cross sectional dependence was not much of a concern. Accordingly, the first generation unit root tests did not take cross sectional correlation into account. The second generation unit root tests, which were developed later, allow cross-sectional dependence in data. In this category, among others, are the Fisher ADF, Fisher PP, MADF, SURADF and the CIPS panel unit root tests. Pesaran (2007) developed a panel unit root test, augmenting the ADF regressions with the cross-section averages of lagged levels and first differences for each unit. In this respect, Pesaran's test differs from the other unit root tests (Dong, et al., 2018).

This study shows stationarity levels of variables using a CIPS panel unit root test developed by Pesaran, (2007), which considers cross-sectional dependence. Pesaran (2007) proposed a simple method to eliminate cross-sectional dependency rather than estimating factor loads. In this method, ADF regression augmented with lagged cross-sectional averages is proposed. The equation discussed is as follows:

$$
\Delta Y_{i t}=a_{i}+\beta_{i} Y_{i t-1}+c_{i} \bar{Y}_{t-1}+d_{i} \Delta \bar{Y}_{t}+\varepsilon_{i t}
$$

where $Y_{i t}$ is the time averages $Y_{i t}$ of and $\varepsilon_{i t}$ is the error term. The null hypothesis is a unit root for all units in the panel. The alternative hypothesis is a stationary process for at least one of the units.

\section{Panel Cointegration}

When econometric modeling is performed with non-stationary panel data at level, a spurious regression problem can be encountered. Since statistical tests will be biased in the presence of spurious regression, appropriate analyzes such as panel cointegration tests should be utilized. There are several panel cointegration tests in 
the literature, some of which allow the cross-sectional correlation and others not. Kao (1999) proposed panel cointegration test that is based on Dickey-Fuller (DF) and Augmented Dickey Fuller (ADF) test. Considering the following panel regression model:

$$
Y_{i t}=a_{i}+\beta_{i} X_{i t}+\varepsilon_{i t}
$$

The DF test can be calculated from the estimated residuals in Equation (3.2).

$$
\hat{\varepsilon}_{i t}=\rho \hat{\varepsilon}_{i t-1}+v_{i t}
$$

where the null hypothesis is constructed as $H_{0}: p=1$. The null hypothesis here is that there is no cointegration. The estimate of " $p$ " is calculated as follows:

$$
\hat{\rho}=\frac{\sum_{i=1}^{N} \sum_{t=2}^{T} \hat{s}_{i t} \hat{s}_{i t-1}}{\sum_{i=1}^{N} \sum_{t=2}^{T} \hat{s}_{i t-1}^{2}}
$$

Kao (1999) proposed four test statistics based on $\mathrm{DF}^{2}$. The important assumption underlying pooled homogeneous models has been called into question. Pedroni (2001) states that the between-dimension estimators are more flexible if the cointegrating vector is heterogeneous. Another favour of the between-dimension estimators is that the point estimates have a more beneficial interpretation in the event that the true cointegrating vectors are not homogeneous (Pedroni, 2001, p.728). Fully modified ordinary least square (FMOLS) and dynamic ordinary least square (DOLS) are widely used in panel data literature to estimate cointegration vectors. These estimators are to account for possible serial correlation and endogeneity of the regressors. The models are based on the regression such as proposed by Pedroni (2001):

$$
Y_{i t}=a_{i}+\beta_{i} X_{i t}+\mu_{i}+\varepsilon_{i t}
$$

where $\beta_{i}$ is heterogeneous across i. from Equation (3.5) regression group-mean panel DOLS estimator is given as:

$$
\beta_{G D}^{*}=\left[N^{-1} \sum_{i=1}^{N}\left(\sum_{t=1}^{T} z_{i t} z_{i t}^{\prime}\right)^{-1}\left(\sum_{t=1}^{T} z_{i t} \tilde{s}_{i t}\right)\right]
$$

where $\mathrm{Z}_{\mathrm{it}}$ is the vector of explanatory variables, $\tilde{s}_{i t}=s_{i t}-\bar{s}_{i}$ and DOLSMG estimator is constructed as $\hat{\beta}_{G D}^{*}=\left[N^{-1} \sum_{i=1}^{N} \hat{\beta}_{D, i}^{*}\right]$, where $\hat{\beta}_{D .}^{*}$ is the known DOLS estimator, applied to the $i$ th member of the panel. t-statistic is then given by

$$
t_{\widehat{\beta}_{G D}^{*}}=N^{-1} \sum_{i=1}^{N} t_{\hat{\beta}_{D, i}^{*}}
$$

2 Kao (1999) also proposed an ADF type of regression. 
where, ${ }^{t} \hat{\beta}_{D, i}^{*}=\left(\hat{\beta}_{D, i}^{*}-\beta_{0}\right) \sqrt{\hat{\sigma}_{i}^{-2} \sum_{i=1}^{T}\left(x_{i t}-\bar{x}_{i}\right)}$. This t-statistic has the standard normal distribution as $\mathrm{T}$ and $\mathrm{N}$ go to infinity (Kim et all., 2005, p.78).

\section{Data and Findings}

\section{Data}

In testing whether the EKC hypothesis is valid empirically, Equation (1.2) was used and data on the D8 countries over the period 1972-2014. The data were obtained from the World Bank-World Development Indicators (WDI) and all the variables are in natural logarithmic. Carbon dioxide emissions $\left(\mathrm{CO}_{2}\right)$ are those stemming from the burning of fossil fuels and the manufacture of cement. The $\mathrm{CO}_{2}$ emission is in metric tons per capita. GDP per capita is gross domestic product divided by midyear population. The data are in constant 2010 U.S. dollars. According to the World Bank's definition, "energy use (energy) refers to the use of primary energy before transformation to other end-use fuels, which is equal to indigenous production plus imports and stock changes, minus exports and fuels supplied to ships and aircraft engaged in international transport". The energy is formed $\mathrm{kg}$ of oil equivalent per capita. The $\mathrm{GDP}^{2}$ and $\mathrm{GDP}^{3}$ are squares and cubes of the GDP, respectively.

\section{Findings}

We started by applying panel unit root tests to scrutinize whether the series included in the analysis were stationary. Before applying the panel unit root tests, we checked the cross-sectional dependence (CD) to decide the appropriate unit root test. Therefore, the weak cross-sectional dependence among the variables was investigated by Pesaran (2015) CD test.

Table 3

Pesaran (2015) - CD Test

\begin{tabular}{ccc}
\hline & CD TEST & P VALUE \\
\hline CO2 & 34.630 & 0.000 \\
ENERGY & 34.680 & 0.000 \\
GDP & 34.671 & 0.000 \\
GDP2 & 34.591 & 0.000 \\
GDP3 & 34.463 & 0.000 \\
\hline
\end{tabular}

Due to the fact that the null hypothesis can be rejected at $1 \%$, there exists crosssectional dependency for all series. The CD test results show that it is appropriate to apply second generation panel unit root tests. The CIPS unit root test of Pesaran (2007) takes into account cross-sectional dependency. The results for CIPS tests, where under the null all panels are non stationary, are given in Table 4: 
$H_{0}: \beta_{i}=0$ for all $\mathrm{i}$

Table 4

Results of CIPS Panel Unit Roots Test

\begin{tabular}{ccccc}
\hline & \multicolumn{2}{c}{ Level } & \multicolumn{2}{c}{ First Difference } \\
\hline CO2 & t-bar & Z [t-bar] & t-bar & Z [t-bar] \\
ENERGY & -1.706 & 0.222 & $-4.161^{*}$ & $-7.164^{*}$ \\
GDP & -1.767 & 0.039 & $-4.782^{*}$ & $-9.032^{*}$ \\
GDP2 & -1.774 & 0.019 & $-3.450^{*}$ & $-5.026^{*}$ \\
GDP3 & -1.695 & 0.255 & $-3.460^{*}$ & $-5.054^{*}$ \\
\hline
\end{tabular}

Table 4 shows that all variables are non stationary at level, but at least one panel is stationary at first differences. After the unit root tests, the cross- dependency among the residuals in the panels is tested with LM test and the result is given at the bottom of Table 5. According to the test result, there is no cross-sectional dependency. The Kao (1999) cointegration test is one of the appropriate tests in the absence of crosssectional dependency. Then, the long-term relationship between the series was tested by Kao (1999) cointegration test. The null hypothesis of the reported cointegration test is no cointegration. The estimation results obtained are shown in Table 5.

Table 5

The Results of Cointegration Test

\begin{tabular}{lcc} 
Kao Test for Cointegration & Statistic & p value \\
Modified Dickey Fuller t & -2.9561 & 0.0016 \\
Dickey Fuller t & -2.0715 & 0.0192 \\
Augmented Dickey Fuller t & -2.4216 & 0.0077 \\
Unadjusted Modified Dickey Fuller t & -3.6043 & 0.0002 \\
Unadjusted Dickey Fuller t & -2.3009 & 0.0107 \\
LM Test for Cross-Dependency & 35.81 & 0.147 \\
\hline
\end{tabular}

The cointegration test results show that there is a long-run relationship between the variables. All tests suggest the rejection of the no cointegration null at $5 \%$ significance level. Due to panel cointegration the test results suggest the presence of a long-run relationship between carbon dioxide emission, GDP, GDP ${ }^{2}, \mathrm{GDP}^{3}$ and energy use. Swamy (1971) test statistic for heterogeneity at the bottom of Table 6 shows that the panel is heterogeneous. Pedroni (2001) DOLS-MG estimator was performed and these results are reported in Table 6. 
Table 6

Long-Run Coefficients

\begin{tabular}{lcccccc}
\hline & GDP & GDP2 & GDP3 & \multicolumn{2}{c}{ Energy } & \multicolumn{2}{c}{ Turning Points } \\
\hline Turkey & $177.9^{*}$ & $-19.7^{*}$ & $0.7267^{*}$ & $1.218^{*}$ & 6679.772 & 10569.48 \\
Banglades & 28.05 & -2.297 & -0.00518 & $3.119^{*}$ & - & - \\
Indonesia & $210.1^{*}$ & $-23.8^{*}$ & $0.8677^{*}$ & $1.173^{*}$ & 1711.807 & 51051.25 \\
Iran & 69.01 & -8.735 & 0.3675 & $0.8257^{*}$ & 1809.256 & 4209.648 \\
Malaysia & $-197^{*}$ & $23.23^{*}$ & $-0.9032^{*}$ & $-0.5792^{*}$ & 2167.267 & 12903.07 \\
Egypty & 21.9 & -2.901 & 0.1341 & 0.06342 & - & - \\
Nigeria & -4765 & 639.9 & -28.62 & 0.4209 & 1387.438 & 2144.037 \\
Pakistan & 104.1 & -15.8 & 0.803 & $1.316^{*}$ & - & - \\
Panel & -543.9 & 73.73 & -3.329 & $0.9446^{*}$ & 1310.013 & 1973.181 \\
\hline
\end{tabular}

Note: Swamy's test statistic: $1810.5^{*}$

The results of pooled mean group (PMG) estimates are given in Table 6. All of the coefficients are significant for Turkey, Indonesia, and Malaysia. However, only the coefficient of the Energy is significant for Bangladesh, Iran and Pakistan. The signs of the coefficients indicates that the relationships between income and $\mathrm{CO} 2$ has an N-shape for Turkey and Indonesia. On the other hand, Malaysia has an inverse $\mathrm{N}$-shape relationship. When all panel results are considered it is seen that there is an inverse $\mathrm{N}$-shaped relationship. Considering the significance of the coefficients, turning points are calculated for countries showing the $\mathrm{N}$-form relationship.

The turning point for Turkey is calculated as $\$ 6,680$ and $\$ 10,570$, respectively. The per capita income levels obtained are within the data range of the sample. Thus, Turkey has reached a level of per capita income whose function is upward. The turning points calculated for Indonesia are levels $\$ 1,712$ and $\$ 51,051$. The peak of the curve is within the data period. However, per capita income level has not reached the $\$ 51,051$ (second turning point). Therefore, the country is far from reaching this point. For Malaysia, the turning points are calculated as $\$ 2,167$ and $\$ 12,903$. The per capita income level in Malaysia is above the first turning point throughout the analysis period. So, the country now seems to be in the downward-sloping stage. ${ }^{3}$ As a result, the turning points are different from country to country. As can be seen, countries are located in different parts of the EKC curve. 'However, countries should intervene to "tunnel" along the curve, by building a bridge between the upper and lower parts of the EKC, without allowing environmental problems to reach their peak.'(Munasinghe 1999).

\section{Conclusion}

In this work, panel cointegration methods were used to investigate the validity of the Environmental Kuznets Curve in D8 countries. The results showed that the Environmental Kuznets Curve is supported empirically for the D8 countries over the period between 1972 and 2014.

3 Other countries have been not interpreted as there are no statistically significant coefficients. 
The findings varies among the D8 countries. The N-shaped EKC curve is found to be valid in three of the eight countries studied. Turkey stands out as the country with the highest first turning point. In addition, Turkey is also located in the downwardsloping stage of the $\mathrm{N}$ curve and hence separated from the other D8 countries. Considering these results, policymakers should immediately constitute policies that aim at reducing carbon emissions. Moreover, the country with the highest per capita energy use and the highest carbon emission is Turkey, followed by Indonesia. In Malaysia, on the other hand, an increase in per capita energy use causes a decrease in the carbon emission. Therefore, Turkey and Indonesia's clean energy use needs to take steps towards encouraging the production to implement the policy. The scope of this study is limited to the D8 countries, aiming to analyze the EKC hypothesis by taking into account the considerations of the country groups with different income levels and the intensity of energy use. The EKC pattern may not occur in the same way, even in similar developing countries. Regardless of the level of development, countries must take measures before environmental degradation reaches an irreversible level.

Hakem Değerlendirmesi: Dış bağımsız.

Çıkar Çatışması: Yazar çıkar çatışması bildirmemiştir.

Finansal Destek: Yazar bu çalıșma için finansal destek almadığını beyan etmiștir.

Peer-review: Externally peer-reviewed.

Conflict of Interest: The author has no conflict of interest to declare.

Grant Support: The author declared that this study has received no financial support.

\section{References}

Ahmed, K., \& Long, W. (2012). Environmental Kuznets Curve and Pakistan: An Empirical Analysis. Procedia Economics and Finance, 1, 4-13.

Allard, A., Takman, J., Uddin, G. S., \& Ahmed, A. (2018). The N-shaped environmental Kuznets curve: an empirical evaluation using a panel quantile regression approach. Environmental Science and Pollution Research, 25(6), 5848-5861.

Baek, J. (2015). Environmental Kuznets curve for CO2 emissions: the case of Arctic countries. Energy Economics, 50, 13-17.

Balin, B. E., \& Akan, D. M. (2015). EKC hypothesis and the effect of innovation: A panel data analysis. Journal of Business Economics and Finance, 4(1).

Borghesi, Simone (1999). The Environmental Kuznets Curve: A Survey of the Literature, Nota di Lavoro, No. 85.1999, Fondazione Eni Enrico Mattei (FEEM), Milano

Brajer, V., Mead, R. W., \& Xiao, F. (2008). Health benefits of tunneling through the Chinese environmental Kuznets curve (EKC). Ecological Economics, 66(4), 674-686.

Cho, C. H., Chu, Y. P., \& Yang, H. Y. (2014). An Environment Kuznets Curve for GHG Emissions: A panel Cointegration Analysis. Energy Sources, Part B: Economics, Planning and Policy, 9(2), $120-129$. 
Dasgupta, S., Laplante, B., Wang, H., \& Wheeler, D. (2002). Confronting the Environmental Kuznets Curve. Journal of Economic Perspectives, 16(1), 147-168.

De Bruyn, S. M., Van Den Bergh, J. C., \& Opschoor, J. B. (1998) Economic Growth and Emissions: Reconsidering the Empirical Basis of Environmental Kuznets Curves. Ecological Economics, 25(2), 161-175.

Dinda, S. (2004). Environmental Kuznets Curve Hypothesis: A Survey. Ecological Economics, 49(4), 431-455.

Dong, K., Sun, R., Li, H., \& Liao, H. (2018). Does Natural Gas Consumption Mitigate CO2 Emissions: Testing the Environmental Kuznets Curve Hypothesis for 14 Asia-Pacific Countries. Renewable and Sustainable Energy Reviews, 94(August 2017), 419-429.

Farhani, S., Mrizak, S., Chaibi, A., \& Rault, C. (2014). The Environmental Kuznets Curve and Sustainability: A Panel Data Analysis. Energy Policy, 71, 189-198.

Grossman, G. M., \& Krueger, A. B. (1991). Environmental Impacts of a North American Free Trade Agreement.

Gündüz, H. İ. (2014). Çevre Kirliliği ile Gelir Arasındaki İlişkinin İncelenmesi: Panel Eşbütünleşme Analizi ve Hata Düzeltme Modeli. Marmara Üniversitesi İ.I.B. Dergisi, 36(1), 409-423.

Jebli, M. Ben, Youssef, S. Ben, \& Ozturk, I. (2016). Testing Environmental Kuznets Curve Hypothesis: The Role of Renewable and Non-renewable Energy Consumption and Trade in OECD Countries. Ecological Indicators, 60(2016), 824-831.

Kao, C., 1999. Spurious Regression and Residual-based Tests for Cointegration in Panel Data. Journal of Econometrics, 90, 1-44.

Kasman, A., \& Duman, Y. S. (2015). CO2 Emissions, Economic Growth, Energy Consumption, Trade and Urbanization in New EU Member and Candidate Countries: A Panel Data Analysis. Economic Modelling, 44, 97-103.

Kim, H., Oh, K. Y., \& Jeong, C. W. (2005). Panel Cointegration Results on International Capital Mobility in Asian Economies. Journal of International Money and Finance, 24(1), 71-82.

Kuznets, S. (1955). Economic Growth and Income Inequality. The American Economic Review, $45(1), 1-28$.

Lee, C. C., \& Lee, J. De. (2009). Income and CO2 Emissions: Evidence from Panel Unit Root and Cointegration Tests. Energy Policy, 37(2), 413-423.

Munasinghe, M. (1999). Is environmental degradation an inevitable consequence of economic growth: tunneling through the environmental Kuznets curve. Ecological economics, 29(1), 89-109.

Opschoor, J.B., 1990. Ecologische duurzame economische ontwikkeling: Een theoretisch idee en een weerbarstige praktijk. In: Nijkamp, P., Verbruggen, H., (Eds.), Het Nederlands Milieu in de Europese Ruimte: Preadviezen van de Koninklijke Vereniging voor Staathuishoudkunde. Stenfert Kroese, Leiden, 77-126.

Osabuohien, E. S., Efobi, U. R., \& Gitau, C. M. W. (2014). Beyond the Environmental Kuznets Curve in Africa: Evidence from Panel Cointegration. Journal of Environmental Policy and Planning, 16(4), 517-538.

Perman, R., \& Stern, D. I. (2003). Evidence from Panel Unit Root and Cointegration Tests that the Environmenta...: EBSCOhost. Australian Journal of Agricultural and Resource Economics, $47(3), 325-347$.

Pedroni, P. (2001). Purchasing Power Parity Tests in Cointegrated Panels. Review of Economics and Statistics, 83(4), 727-731. 
Pesaran, M. H. (2007). A Simple Panel Unit Root Test in the Presence of Cross-Section Dependence. Journal of Applied Econometrics, 22, 265-312.

Pesaran, M. H. (2015). Testing Weak Cross-sectional Dependence in Large Panels. Econometric Reviews, 34(6-10), 1089-1117.

Pezzey, J., 1989. Economic Analysis of Sustainable Growth and Sustainable Development. Environment Department. Working Paper No: 15, The World Bank, 81.

Roca, J. (2003). Do Individual Preferences Explain the Environmental Kuznets Curve? Ecological Economics, 45(1), 3-10.

Shafik, N., \& Bandyopadhyay, S. (1992). Economic Growth and Environmental Quality: TimeSeries and Cross-country Evidence (Vol. 904). World Bank Publications.

Shuai, C., Chen, X., Shen, L., Jiao, L., Wu, Y., \& Tan, Y. (2017). The Turning Points of Carbon Kuznets Curve: Evidences from Panel and Time-series Data of 164 Countries. Journal of Cleaner Production, 162, 1031-1047.

Stern, D. I. (2004). The Rise and Fall of the Environmental Kuznets Curve. World Development, 32(8), 1419-1439.

Swamy, P. A. (1971). Statistical Inference in Random Coefficient Regression Models. (Vol. 55). Springer Science \& Business Media.

Yerdelen Tatoğlu, F., \& İçen, H. (2019). Çevresel Kuznets Eğrisinin Çok Boyutlu Panel Veri Modelleri ile Analizi. Anadolu Iktisat ve İşletme Dergisi, 3(1), 26-38.

Zoundi, Z. (2017). CO2 emissions, Renewable Energy and the Environmental Kuznets Curve, A Panel Cointegration Approach. Renewable and Sustainable Energy Reviews, 72(July 2016), 1067-1075. 